\title{
A Possible Genetic Pattern of Taurine Urinary Excretion in Friedreich's Ataxia
}

\author{
A. BARBEAU, F. PATENAUDE, G. NADON, M. CHARBONNEAU, T. CLOUTIER
}

SUMMARY: The taurine urinary excretion pattern, before and after an oral load of $250 \mathrm{mg}$ taurine, was studied in normal control subjects and in patients with typical Friedreich's ataxia. It was demonstrated that in both situations the ataxic patients fell within the sub-types of "intermediate" and "high taurine excretors", while none were "low taurine excretors". It was also demonstrated that the excretion of taurine after a load in the obligate heterozygotes parents of the ataxic patients was intermediate between normal controls and patients. It is postulated that patients with Friedreich's Ataxia lack

RÉSUMÉ: Nous avons examiné le patron d'excrétion urinaire de la Taurine, avant et après une surcharge orale de $250 \mathrm{mg}$, chez des sujets témoins normaux et chez des patients souffrant d'ataxie de Friedreich typique. Nous avons démontré que dans les deux situations les patients ataxiques se situaient parmi les "excréteurs intermédiaires" ou les "excréteurs élevés" de taurine, alors qu'aucun ne se rangeait parmi les "excréteurs bas". Nous avons également démontré que chez les porteurs obligatoires (les parents d'ataxiques), l'excrétion est intermédiaire entre celle des sujets témoins et celle des patients. Nous postulons que les patients souffrant d'ataxie de Friedreich sont déficitaires dans la régulation du système de normal regulation of the high affinity-low capacity uptake system for taurine (the TH system) in the brush border of kidney tubules. The low affinity-high capacity uptake system in the same membranes (the $T L$ system) appears to be normal in Friedreich's patients. The normal allele could be called $\mathrm{TH}_{N}$ and the variant $\mathrm{THF}$ and this trait would be inherited in an autosomal recessive fashion if it is linked to the Freidreich phenotype. Whether this finding is or is not the basic genetic defect in Friedreich's Ataxia will require more studies to clarify, but it is of interest to note that a similar pattern appears to be present in the fibroblasts of these patients.

réabsorption à haute affinité mais basse capacité de la Taurine (le système TH, situé dans les cellules de la membrane à bordure en brosse des tubules rénaux). Par contre la régulation du système de réabsorption de la taurine à basse affinité mais haute capacité (le système TL) semble être normale dans l'ataxie. Nous appellerons l'allèle normal $T_{N}$ et le variant THF présumant que ce trait, s'il est lié au phénotype Friedreich, serait transmis selon le mode autosomal récessif. Beaucoup d'autres études seront nécessaires pour préciser si ce trait est primaire dans l'ataxie de Friedreich. Il est cependant intéressant de noter qu'un patron semblable se dessine dans les fibroblastes de ces patients.
Department of Neurobiology, Clinical Research Institute of Montreal.

Reprint requests for the complete supplement on Friedreich's Ataxia (Phase Three, Part Two) to: Prof. Andre Barbeau, Clinical Research Institute of Montreal, 110 Pine Avenue West, Montreal, Quebec, Canada, H2W IR 7.

\section{INTRODUCTION}

Taurine concentrations have been determined with precise methods in a number of tissues and fluids from patients with the typical form of Friedreich's ataxia. While blood (Lemieux et al, 1976) and CSF (Lemieux et al, 1978) concentrations are entirely within normal limits, we found that urinary excretion of taurine is doubled in Friedreich's patients (Lemieux et al, 1976). $\beta$-alanine excretion was also shown to be significantly increased. This apparent taurine loss was confirmed through studies where patients were given a uniform taurine load $(250 \mathrm{mg}$ ) and timed urine samples collected (Filla et al, 1979). Again the ataxic subjects excreted twice as much of the taurine load as the age-matched controls. A high urinary excretion of taurine has been observed in a number of physiological as well as pathological conditions, particularly after stress, corticosteroids, "idiopathic" scoliosis, and familial cerebellar dyssynergia (for reviews see: Jacobsen and Smith, 1968; Huxtable and Barbeau, 1976; Barbeau and Huxtable, 1978; Huxtable and Pasantes-Morales, 1982).

It thus appeared that ataxic patients could not retain taurine as well as normal subjects. In view of the normal blood concentrations previously demonstrated, this loss could be due to a defect in tubular uptake or reuptake mechanisms or to a decrease in the total muscle mass which normally holds more than $70 \%$ of the body pool of taurine. In further studies it was reported that uptake of taurine into platelets (Filla et al, 1978) and in cultured fibroblasts (Melançon et al, 1980) appeared to give mean results within the normal control range. A 
localized renal transport defect for taurine or $\beta$-alanine was, of course, not ruled-out by these investigations.

There is only one study available on the concentration of taurine in tissues of Friedreich's Ataxia patients (Huxtable et al, 1979) and this revealed, in two patients, an increased concentration in the cerebellum, in areas where both aspartate and glutamate concentrations were considerably decreased. (For reviews on these studies see: Barbeau et al, 1982). In the cardiomyopathic hamster, however, there is a deficiency in taurine concentration in other tissues such as the heart. (see Azari et al, 1979).

Recently an investigation in epileptic patients by Goodman and collaborators (1980) threw new light on the problem of urinary excretion of taurine. These authors demonstrated that there could be three taurine excretor classes, possibly under genetic control (low, intermediate and high excretors). Epileptics include disproportionate numbers of low excretors, who are presumptive homozygotes for the allele affecting higher reabsorption. Subjects with Down's syndrome also have an excess of very low excretors of taurine (Goodman et al, 1964). These authors hypothesize the presence of a polymorphic pair of co-dominant alleles linked to chromosome 21 to account for the excess of low excretors of taurine among subjects with Down syndrome. These differences were best illustrated after a taurine load. Under these conditions, approximately 12 $15 \%$ of normal subjects are low excretors, the rest being intermediate or high excretors.

In view of our own findings of high taurine excretion in Friedreich's Ataxia, and of the above reports, the present study was initiated to investigate a possible distinct excretion pattern in that illness, perhaps under genetic control.

\section{SUBJECTS AND METHODS}

In the first study 18 patients (mean age $24 \pm 1.8$ years) with the typical picture of Friedreich's Ataxia as described by Geoffroy et al, (1976) were investigated in the out-patient metabolic unit of the Clinical Research Institute of Montreal. Six parents of Friedreich's Ataxia patients (obligate heterozygotes) were investigated at the same time. These included two men and four women; mean age 47. For each patient, two normal unrelated control subjects of similar age $( \pm 4$ years) and sex were also studied with the same protocole. All subjects abstained from fowl, meat and shell fish for three days prior to the experiment; they also fasted for 12 hours prior to the start and for the 6 hours of the experiment. At time zero, overnight urine was collected and immediately frozen for determination of taurine, creatinine and inorganic sulfate. Immediately afterwards the subjects ingested a capsule containing $250 \mathrm{mg}$ of taurine. Urine was collected, in two hour samples, for the next 6 hours. The patients were graded as to severity according to the scale described by Pourcher and Barbeau (1980).

In a second study we investigated the familial pattern of taurine excretion, before and after a taurine load, in seven control families (14 parents and 20 children) and six Friedreich families (12 parents, 7 healthy siblings and 9 patients with typical Friedreich's Ataxia). Each of these subjects underwent the taurine load test with $250 \mathrm{mg}$ oral taurine. Only a 2 hour collection was made for this study. The excretor type of each subject, at time zero, was determined using the intermodes obtained in the first study (see infra).

Creatinine and inorganic sulfate were determined through standard methods. Urinary taurine was measured by the method of Anfano et al, (1978).

\section{RESULTS}

As seen in Fig. 1 the distribution of urinary excretion patterns at time 0 (expressed in units as the logarythm of $\mathrm{mg}$ taurine/g creatinine) in normal control subjects demonstrates the existence of low, intermediate and high excretors with postulated intermodes, according to Goodman et al, (1980), at

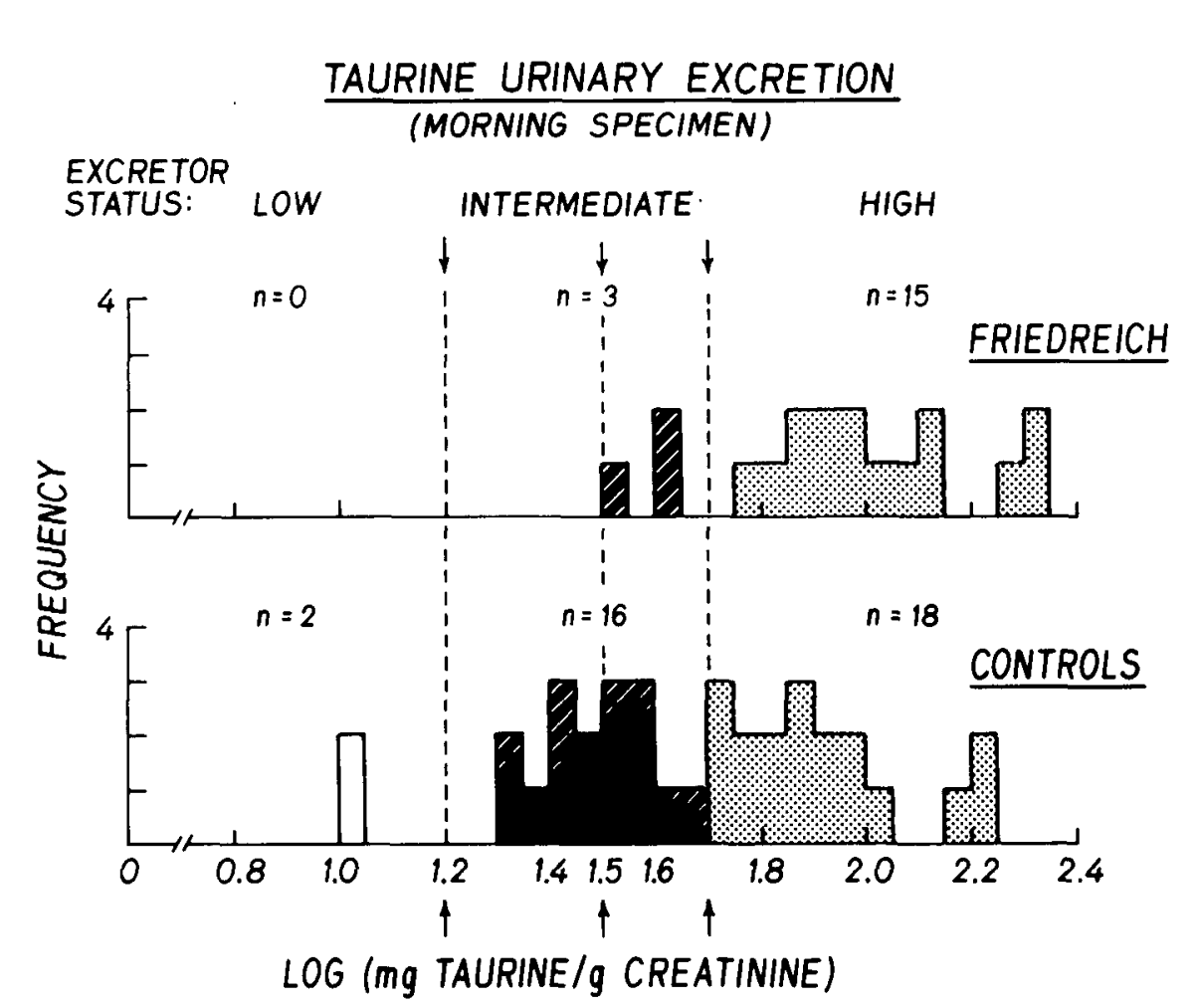

Figure 1 - Pattern of taurine urinary excretion in normal control subjects and patients with Freideich's Ataxia at time zero. Arrows indicate intermodes. 


\section{TAURINE URINARY EXCRETION AFTER}

\section{TAURINE LOAD (250 mg)}

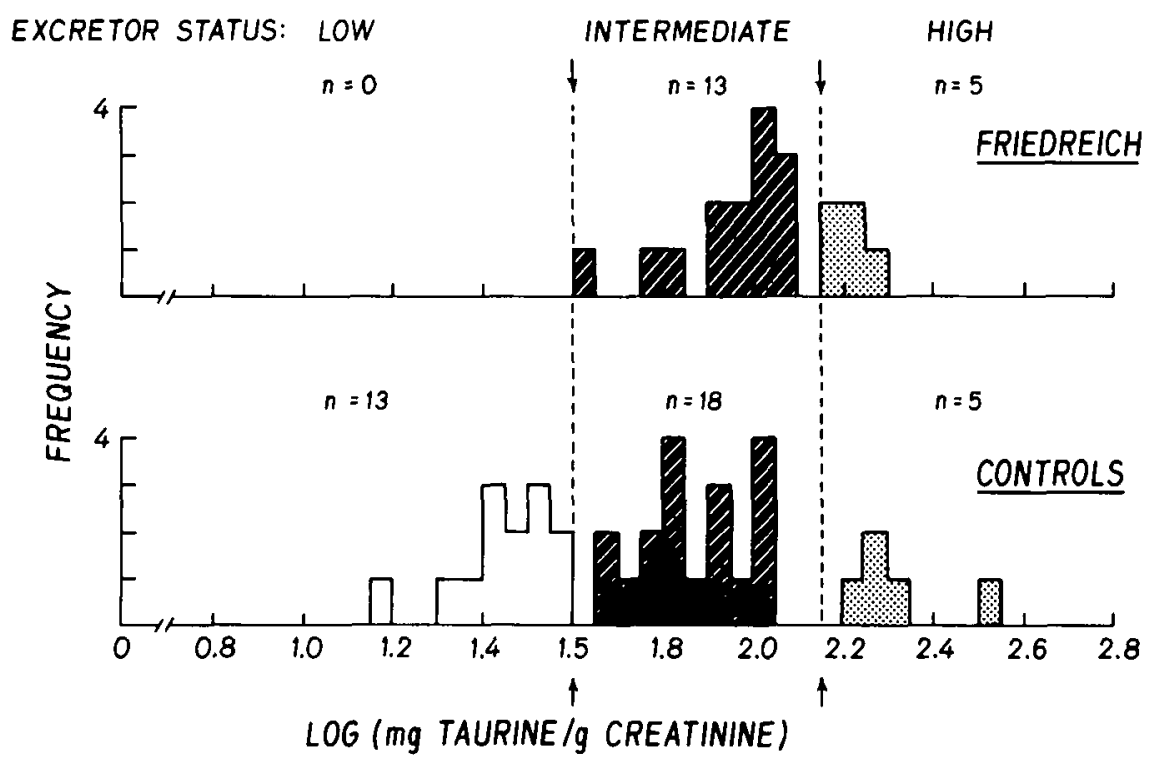

Figure 2 - Pattern of taurine urinary excretion at two hours after an oral taurine load of $250 \mathrm{mg}$ in normal control subjects and patients with Friedreich's Ataxia. Arrows indicate intermodes.

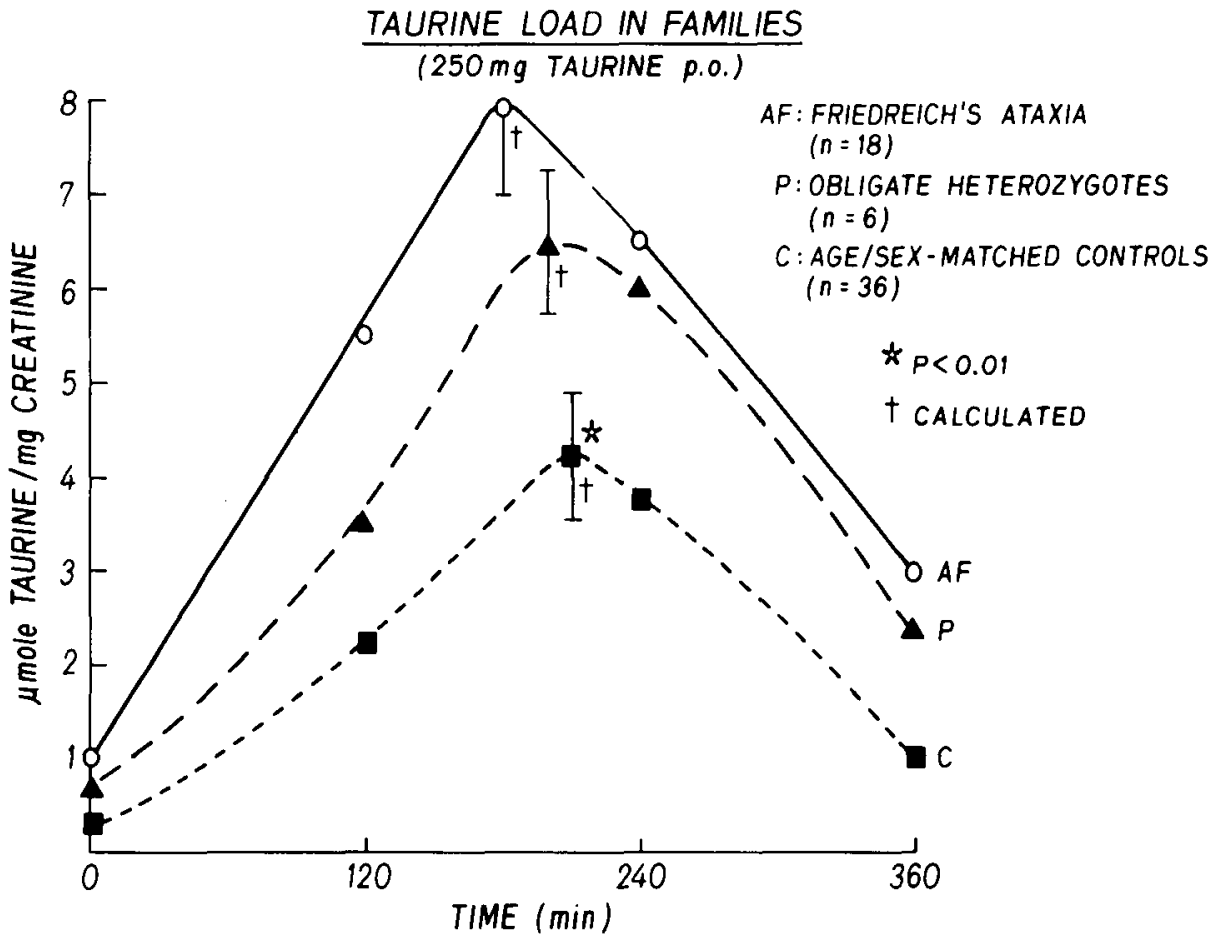

Figure 3 - Oral taurine load of $250 \mathrm{mg}$ per subject. Urine collection were made every 2 hours for 6 hours. Peak levels were estimated from the slope of the curves. For clarity only, the peak level standard deviations are indicated, but each point in the ataxic curve was statistically different from the same point for the controls $(\mathrm{p}<0.01)$.
1.2 and 1.7 units and relative percentage distributions of 6,44 and $50 \%$. If instead a median of 1.5 units is accepted as separating low and high excretors, then the distribution is 28 to $72 \%$ for these two patterns in normal control subjects. In contrast, the distribution pattern in Friedreich's Ataxia is totally different: low excretors $(0 \%)$, intermediate excretors (17\%), high excretors $(83 \%)$, with the most striking variation evident when only two phenotypes are considered with a median of 1.5 units: $0 \%$ of patients are low excretors (below 1.5 units) and $100 \%$ high excretors. The difference is highly significant by Fisher Exact Probability tests $(\mathrm{p}<0.01)$

The same pattern is observed 2 hours after a load of $250 \mathrm{mg}$ of taurine (Fig. 2). In normal controls, $36 \%$ are low, $50 \%$ intermediate and $14 \%$ high excretors while in Friedreich's patients the corresponding figures are: $0 \%, 72 \%$ and $28 \%$ respectively. If only two phenotypes are considered, $36 \%$ of controls, but $0 \%$ of patients are low excretors while the figures for high excretors are $64 \%$ and $100 \%$, respectively. Again the differences are highly significant $(p<0.01)$ by Fisher Exact Probability tests.

We also studied the excretion pattern of taurine 2, 4, and 6 hours after taurine ingestion $(250 \mathrm{mg})$ in 18 patients, 6 of their parents who are obligate heterozygotes, and 36 control subjects. As can be seen in Fig. 3, the patients excreted significantly more taurine at all points of the curve than the control subjects. The new results confirm those reported by Filla et al, (1979). In addition we were able to show that the obligate heterozygotes place almost exactly mid-way between the controls and the patients, as would be expected in an autosomal recessive disorder, if the trait is linked to the genotype.

In the second study (the investigation of 7 control and 6 ataxic family groups), we confirmed the same pattern. As seen in Table 1, only the ataxic subjects are significantly different in taurine excretion from their siblings, their parents and all control 
TABLE 1

TAURINE URINARY EXCRETION AFTER TAURINE LOAD $(250 \mathrm{mg})$

\section{A FAMILY STUDY}

Taurine excretion (mg/g creat.)

GROUPS

N TIME O TIME 2 HOURS

\% INCREASE

A. Seven control families
a) Parents
14
$62 \pm 5$
$247 \pm 12$
$378 \pm 22$
b) Children
20
$65 \pm 6$
$271 \pm 14$
$317 \pm 19$

B. Six Friedreich families
a) Parents
12
$72 \pm 6$
$320 \pm 18$
$348 \pm 16$
b) Siblings
$56 \pm 4$
$274 \pm 11$
$339 \pm 22$
c) Ataxics
$106 \pm 9 *$
$491 \pm 22 *$
$356 \pm 20$

* $p<0.05$

\section{TAURINE UPTAKE IN FIBROBLASTS}

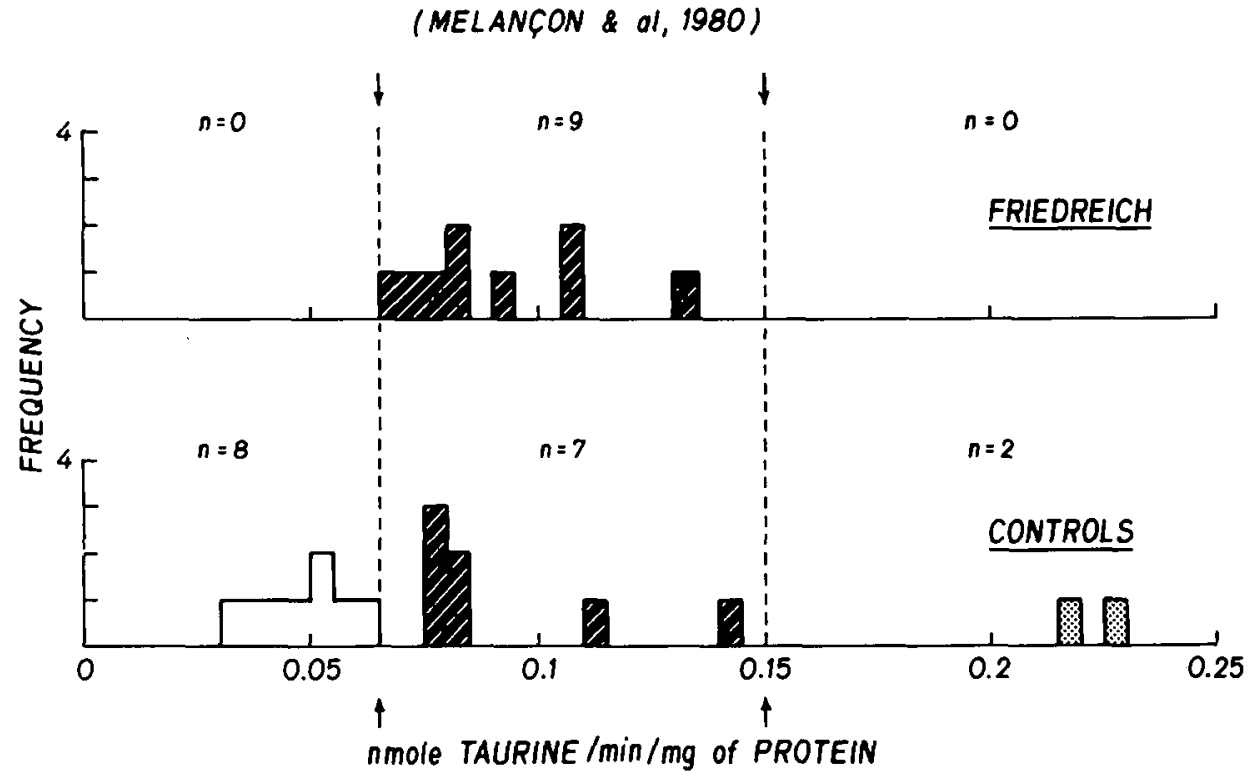

Figure 4 - Representation of taurine uptake in fibroblasts at a final concentration of $30 \mu \mathrm{M}$. The incubation medium consisted of $1 \mathrm{mM}$ tris (hydroxymethyl) aminomethane buffer at $\mathrm{pH} 7.4$, containing $0.1 \%$ glucose and the test compounds. The uptake experiments were done at $37^{\circ} \mathrm{C}$. The experiments were performed on cells between their 7 th and 20th passage. Arrows indicate intermodes. Uptake measured was probably at basilar membrane. Data replotted, with permission, from Melançon et al, (1980). subjects. This difference persisted after taurine load. It is noteworthy that the percentage increase in all groups, including the ataxics, was similar indicating that the difference is significant below a certain threshold. Parents of ataxics are intermediate between normal controls or siblings of ataxics and the patients themselves.

\section{DISCUSSION}

The most striking finding of the above results is not that there is a relative (or even absolute) excess of high excretors in Friedreich's Ataxia, both in resting conditions (Fig. 1) and after a taurine load (Fig. 2), but that not a single patient with typical Friedreich falls within the "low excretor" group in both tests. It is of course difficult to be certain of the exact intermodes between groups and whether one or two intermodes should be used, until a much larger control series has been compiled, but no matter what division we adopt, there is no doubt that patients and controls have a significantly different distribution pattern. If we accept only a division based on clinical observation of the "urinary phenotype", with a dividing line at 1.5 units $[\log (\mathrm{mg}$ taurine/g creatinine)], it is evident that all Friedreich patients fall within the "high excretor" group or, more correctly, that none belong to the "low excretor" group. If, on the other hand, we accept the intermodes defined by Goodman et al, (1980), we still find that none of the Friedreich patients are low excretors, 3 (of the 18) are intermediate excretors and 15 are high excretors. The Friedreich patients behave as if their tubular reuptake system at low concentrations of taurine did not function properly.

Following this observation we reinspected the data on taurine uptake in fibroblasts from the study of Melançon et al, (1980). With their permission we produce in Fig. 4 the same data (their Fig. 1) replotted to conform to our previous illustrations. Although mean uptake values are almost identical, it is now readily apparent that none of the Friedreich's Ataxia patients have low uptake values, as opposed to $47 \%$ of the controls. It is 
therefore possible that the defect apparently observed at the level of the kidney proximal tubule is also present in fibroblasts. What is that defect?

The studies of Chesney and collaborators (1976) in hypertaurinuric mice may provide some clues. In these mice (C57BL/6J and PRO/RE) the fractional reabsorption of taurine is $84 \%$ and $79 \%$ respectively, compared to $97 \%$ for the normal taurine excretor mice $(A / J)$, despite normal plasma taurine concentrations. With a maximum decrease of $20 \%$ in tubular reabsorption capacity, taurinuria is 10 fold greater in the mutant strains. Taurine behaves as an inert metabolite in mouse kidney cortex slices. Taurine uptake by mouse kidney outer cortex slices is active and, at $<1 \mathrm{mM}$, is greater than normal in the mutants.

Concentration-dependent uptake studies reveal more than one taurine carrier in mutant (called taut) and normal (tau ${ }^{t}+$ ) strains. Chesney et al, (1976) found that the apparent $\mathrm{Km}$ values for uptake below $1 \mathrm{mM}$ (high affinity) are different in tau ${ }^{\mathrm{t}-}$ and tau ${ }^{\mathrm{t}+}$ slices $(\sim 0.2 \mathrm{mM}$ and $\sim 0.7 \mathrm{mM}$, respectively). Thus at low $\mathrm{Km}$, apparent uptake of taurine seems to be more avid in the mutant.

The apparently greater affinity for taurine uptake in taut- strains at low substrate concentrations is a function of the higher uptake observed in these strains at that concentration. After uptake by slices, taurine appears to be partially sequestered in the lumen, under steady-state conditions, and a higher taurine uptake ratio is observed because the luminal "lacuna" comes to retain more taurine in the presence of impaired reclamation from that lacuna. This will cause an apparent decrease in $\mathrm{Km}$ value, all other components of the Michaelis equation being equal. The lowering of the $\mathrm{Km}$ at low concentrations of taurine in the mutant strains is therefore not a reflection of more avid binding and uptake at the basilar membrane. In the mouse, the apparent $\mathrm{Km}$ values above $1 \mathrm{mM}$ are similar in both groups. Efflux from slices in all strains is the same, but tauttissue appeared to retain about $10 \%$ more radioactivity over the period of efflux. The authors conclude that the

\section{TAURINE RE-UPTAKE MECHANISM}

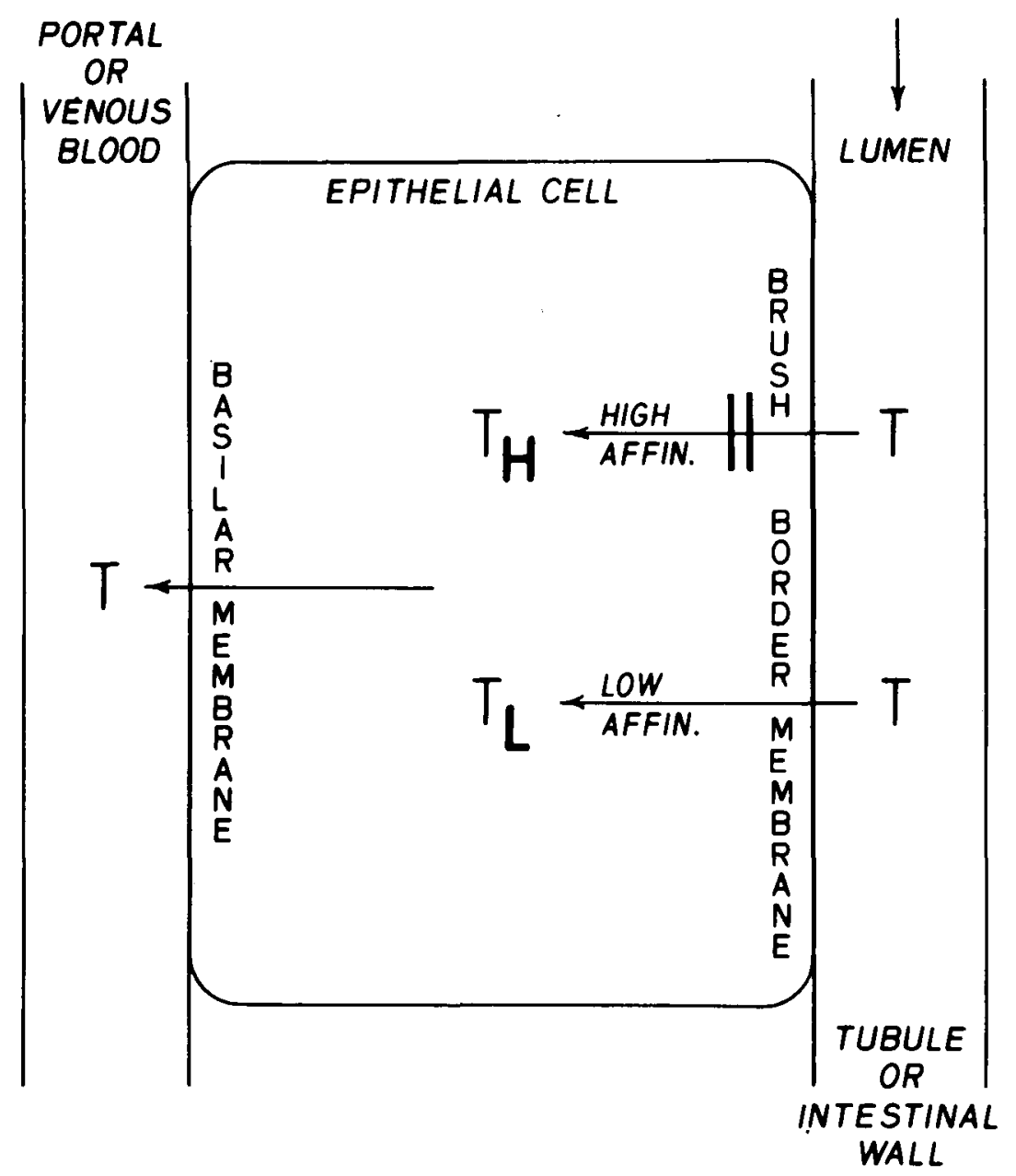

Figure 5 - Schematic representation of the mechanisms of reuptake of taurine from the kidney tubular lumen. Two uptake systems are thought to exist at the brush border membrane: the $\mathrm{TH}$ system (high affinity, low capacity) and the TL system (low affinity, high capacity). In Friedreich's Ataxia we postulate a block (partial or complete?) in the TH system. The same diagram could be used to illustrate the events in the intestinal luminal membrane and possibly in the fibroblasts. T represents taurine.

findings indicate impaired $\beta$-amino acid permeation on a low-Km uptake system at the luminal membrane in the tau ${ }^{\mathrm{t}-}$ phenotype. $\beta$-amino acids are not reclaimed efficently either from the innermost luminal pool in cortex slices or from the ultrafiltrate in the tubule lumen in vitro. According to the authors, the former leads to high uptake ratios in vitro, the latter to high clearance rates in vivo. In vitro and in vivo data thus seem to be concordant. Moreover they state that there is a genetic independance of basilar and luminal $\beta$-amino acid transport systems (Scriver and Hetchtman, 1970).
Fig. 5 illustrates our understanding of how such studies could apply to the problem of kidney taurine transport in humans with Friedreich's Ataxia. Recent work by Ullrich and Fromter (1978) has suggested that amino-acid transport in contraluminal plasma membrane of Kidney tubular epithelium differs from basal-lateral membranes and behaves more like the fibroblast transport systems. Fibroblasts would then appear suitable for investigation of amino-acid conservation defects present in kidney and/or intestinal cells. In the brush border membrane there exist two 
uptake systems for taurine: one with a high affinity (low $\mathrm{Km}$ ) and a small capacity, which we will call the TH system, and another with low affinity (high $\mathrm{Km}$ ) but high capacity, which we will call the TL system. All the above studies in vivo and in vitro, when taken together, would tend to favour the existence of a defect in the high affinity system (the $\mathrm{TH}$ system) in patients with Friedreich's Ataxia. This system functions preferentially at low concentrations of substrate. At high concentrations the low affinity system (the TL system) takes over, and almost completely compensates for the defective TH system.

It is of great interest that obligate heterozygotes (parents of Friedreich's Ataxia patients) have taurine urinary excretion values situated mid-way between their affected offsprings and normal control subjects. This would be the expected observation if the trait under study were of autosomal recessive nature, or closely linked to the gene product. It is however too early to draw firm conclusions at this time before the genetics of the TH and TL systems of taurine transport have been better worked out in normal subjects.

At any rate our evidence leads us to offer the following working hypothesis: Patients with Friedreich's Ataxia lick proper regulation of the high affinitylow capacity uptake system (" $\mathrm{TH}$ System") for taurine in the brush border membrane of kidney tubules. This abnormal trait may be genetically determined (based on findings in obligate heterozygotes) or closely linked to the gene product. An explanation of how the presence of this trait relates to the known biochemical and physiological abnormalities in Friedreich's Ataxia will be attempted by Barbeau in another paper of this issue. For purposes of further discussion, we propose to call the trait regulating the normal high affinity $\mathrm{TH}$ system, the $\mathrm{TH}_{\mathrm{N}}$ trait, while that regulating a defective high affinity $\mathrm{TH}$ system in Friedreich's Ataxia, the $\mathrm{TH}_{\mathrm{F}}$ trait. If a recessive pattern of inheritance is postulated, the genotype of normal subjects would be $\mathrm{TH}_{\mathrm{N}} \cdot \mathrm{TH}_{\mathrm{N}}$, that of obligate heretozygotes (the parents): $\mathrm{TH}_{\mathrm{N}} \cdot \mathrm{TH}_{\mathrm{F}}$ and that of patients
$\mathrm{TH}_{\mathrm{F}} \mathrm{TH}_{\mathrm{F}}$. A patient with the latter genotype would rely mainly on his TL system for the reuptake of taurine. The resultant "excretor pattern" would depend directly on the threshold for this TL system, and on the glomerular filtered load of taurine. Assuming steady state values for these variables, at a fixed but low load level, patients with Friedreich's Ataxia would reabsorb less of the taurine, thus excrete more in the urine. At higher load concentrations the differential will decrease because, after a certain threshold, most of the extra taurine load is lost in the urine, in both normal controls and patients.

Many unanswered questions will have to be faced before this working hypothesis becomes fact. For example, one may ask whether the trait is also manifested in the intestinal brush border membrane, where it would also markedly disturb taurine balance in the entero-portal circulation and in the bile. Furthermore, it will be extremely important to directly confirm its presence in fibroblasts studied under the proper conditions of low substrate concentrations. Finally the specificity of the trait to Friedreich's Ataxia must be examined in other genetic spinocerebellar degenerations and, if possible, in an animal model of the disease.

\section{ACKNOWLEDGEMENTS}

The studies reported in this paper were supported by grants from l'Association canadienne de l'Ataxie de Friedreich and the Fondation $\mathrm{O}$. Mallette of the Hôtel-Dieu Hospital. The authors would like to thank Miss Suzanne Paris for nursing assistance and Mrs. Hèlène Crête for typing the manuscript. The helpful advise of Dr. Serge Melançon is gratefully acknowledged.

\section{REFERENCES}

ANFANO, M.A., NAEWANIJ, J.O. and LAMB, A.I. (1978). Simplified two-step column chromatographic determination of taurine in urine. Clin. Chem. 24: 321-325.
AZARI, J, REISINE, R,, BARBEAU, A., YAMAMURA, H.I. and HUXTABLE, R.J. (1979). The Syrian Golden Hamster: a model for the cardiomyopathy of Friedreich's Ataxia. Can. J. Neurol. Sci. 6: 223-226.

BARBEAU, A. (1982). Taurine and Friedreich's Ataxia: an update. in: Taurine in Nutrition and Neurology. Edited by R.J. Huxtable and H. Pasantes-Morales, Plenum Publishing, pp. 389-399.

BARBEAU, A. and HUXTABLE, R.J., Editors (1978). Taurine and Neurological Disorders, Raven Press, New York.

CHESNEY, R.W., SCRIVER, C.R., MOHYUDDIN, F. (1976). Localization of the membrane effect in trans epithelial transport of taurine by parallel studies in vivo and vitro in hypertaurinuric mice. $J$. Clin. Invest. 57: 183-193.

FILLA, A., BUTTERWORTH, R.F., GEOFFROY, G., LEMIEUX, B. and BARBEAU, A. (1978). Platelet taurine uptake in spino-cerebellar degeneration. Can. J. Neurol. Sci. 5: 119-123.

FILLA, A., BUTTERWORTH, R.F. and BARBEAU, A. (1979). Pilot studies on membranes and some transport mechanisms in Friedreich's Ataxia. Can. J. Neurol. Sci. 6: 285-289.

GEOFFROY, G., BARBEAU, A., BRETON, G., LEMIEUX, B., AUBE M., LEGER, C. and BOUCHARD, J.P. (1976). Clinical description and Roentgenologic evaluation of patients with Friedreich's Ataxia. Can. J. Neurol. Sci. 3: 279-286.

GOODMAN, H.O., CONNOLY, B.M., McLEAN, W. and RESNICK, M. (1980). Taurine transport in Epilepsy. Clin. Chemistry 26: 414-419.

GOODMAN, H.O., KING J.S. and THOMAS, J.J. (1964). Urinary excretion of beta-aminoiso-butyric acid and taurine in mongolism. Nature 204: 650-652.

HUXTABLE, R., AZARI, J., REISIN, T., JOHNSON, P., YAMAMURA, H.I., BARBEAU, A. (1979). Regional distribution of amino acids in Friedreich's Ataxia brains. Can. J. Neurol. Sci. 6: 255 258.

HUXTABLE, R.J. and BARBEAU, A., Editors (1976). Taurine. Raven Press, New York.

HUXTABLE, R.J. and PASANTESMORALES, H. (1982) Editors. Taurine in Nutrition and Neurology. Advances in Exper. Med. Biol. V. 139, Plenum Press, New York.

JACOBSEN, J.G. and SMITH, L.H. (1968). Biochemistry and Physiology of Taurine and Taurine Derivatives. Physiol. Reviews 48: 424-511. 
LEMIEUX, B., BARBEAU, A., BERONIADE, V., SHAPCOTT, D., BRETON, G., GEOFFROY, G. and MELANCON, S. (1976). Amino acid metabolism in Friedreich's Ataxia. Can. J. Neurol. Sci. 3: 373-378.

LEMIEUX, B., GIGUERE, R., BARBEAU, A., MELANCON, S. and SHAPCOTT, D. (1978). Taurine in cerebrospinal fluid in Friedreich's Ataxia. Can. J. Neurol. Sci. 5: 125-129.
MELANCON, S.B., GRIGNON, B., LEDRU, E., GEOFFROY, G., POTIER, M., DALLAIRE, L. and VANASSE, M. (1980). The Beta-amino acid transport system in Friedreich's Ataxia. Can. J. Neurol. Sci. 7: 441-446.

MELANCON, S.B., GRIGNON, B., POTIER, $M$. and DALLAIRE, L. (1979). Taurine and Beta-alanine uptake in cultured human skin fibroblasts from patients with Friedreich's Ataxia. Can. J. Neurol. Sci. 6: 251-253.
POURCHER, E. and BARBEAU, A. (1980). Field testing of an Ataxia scoring and staging system. Can. J. Neurol. Sci. 7: 339344.

SCRIVER, C.R. and HECHTMAN, P. (1970). Human genetics of membrane transport with emphasis on amino acids. Adv. Hum. Genet. $1: 211-274$. 